\title{
Religion and democracy
}

\begin{abstract}
Different discussions about separation of religion and politics and secularism motivated this thought that is there any consistency between religious society and democracy or not. The starting point in the discussions is the lack of democracy in religious community and totalitarian nature of society from scientific and technological aspects. The belief that the religious community cannot tolerate various views motivated me to think more in this regard and the result is the present study to use inductive method and evaluate the details and reach generalities that religion can not negate democracy. The main question of study is whether religion and democracy are combined? The exiting hypotheses show that individualistic approaches in human communities are better than religious approach. Individualistic approaches are mostly based on democracy basics. Religion is the origin of real democracy in human communities. The important hypothesis in this study is accepting the main position of human being and his real origin is its consistency on Sharia. The variables of study are different human communities the thought origin of communities, awareness of society to religious orders, the relationship of society with the God speech soul via perceiving Quran, historical and political history of society, thought evolution in joining process to global village and other variables as they can change the inference of human aspects and God speech.
\end{abstract}

Volume I Issue 2 - 2017

\section{Javad bahmani}

Azad University, Iran

Correspondence: Javad bahmani, Azad University, Iran, Tel 989131093121, Email javadbahmanistu@gmail.com

Received: October 14, 2016 | Published: April 03, 2017

\section{Explanation}

In investigation of democracy from the government of cities and then raising it in 16th century with two Greek terms Demos people and Kratos government in various forms in political systems are shown, from monocracy or aristocracy, oligarchy following their own benefits. In democracy, there are many definitions and some of them consider instinct of democracy as an ideal. According to Ibrahim Lincoln, democracy is governance of people by people and with their vote. Karl Cohen defines democracy as a definition: Democracy is the governments in which society members directly or indirectly are participate in their relevant decisions.

\section{David hold says}

The basis of democracy as emphasized by democracy followers' theorists is the ability of citizens in replacing a government with another one and it is supporting against the risk that decision makers change themselves into a constant force ${ }^{1}$ Giarmi believes that democracy is the structure of institutions but real power is dedicated to the rulers as selected. ${ }^{2}$ Jovani Sarturi believes that "Democracy is the name of grandiloquence not being existing externally. According to Webster new collegiate dictionary there is such meaning for democracy, Democracy is the control of power not in an individual and not special group and it is on the hand of public as applied via selected agents via party's channel.

David Hold says almost the key of empirical theorists despite the different views is as democracy is defined as a set of institutional arrangements making a political context and various minority government as possible. ${ }^{3}$ The definition as accepted is as democracy is government of people on people by representatives of people.

There are some ambiguities in this definition as followings.

${ }^{1}$ David Hold, Democracy models, Translated by Abbas Mokhber, 253.

${ }^{2}$ Giarme, Democracy culture, Translated by Morteza Sagheb, 21

${ }^{3}$ David Hold, Democracy models, Translated by Abbas Mokhber, 295.
1. Is definite wealth as the condition of enjoying ownership right on destiny or not? The investigation of the selection of people and the need to high investment to participate in election or a system doesn't create "oligarch of capitalists".

2. Can women interfere in politics as men? To the mid-20th century, women were deprived of such right. Voting was given to Swiss women in 1980 s with the agreement of men.

3. What is the role of minority in this political system? How can we maintain their rights? How can we prevent dictatorship of majority? In France, the majority decided to prohibit Hijab, the condition of democrats is not observing the right of minorities?

4. Mill writes ruthlessness and giving priority of majority is one of the basic losses that the society should be careful to it. ${ }^{4}$ What is the position of majority in government in formation of democracy?

5. Antony Arblaster says about the role of majority in England: In the past four years ago, no government in England is selected with the majority of votes and any government is the agent of the greatest minorities of those giving vote. ${ }^{5}$

6. In democracy, people will is unlimited or it should be controlled?

7. In contradiction between freedom and equality, which one is prior?

Do people resign their representatives any time? Do they interfere in their performance, or they are selected as chief? What is the guarantee to observe the view of clients? If the view of clients was in contradiction with the national benefits, it should be observed as he is a representative? Is democracy an ideological thought and social philosophy? Thus, it explains some ambiguities regarding

${ }^{4}$ John Stewart Mill, thesis about freedom, translated by Javad Sheikholeslami, 32.

${ }^{5}$ Antofi Arblaster, Translated by Hassan Mortezavi, p.15. 
power distribution? Thus, it is a form not defining its content and it can be religious thought (religious democracy) liberal thought (liberal democracy). ${ }^{1}$ In all views presented by democracy, the common field is "accepting people right in government and attempting to the votes and views in policy making and macro national decisions and all theorists supporting democracy believe that they support people rights in accepting their rights in their destiny.

The support of political democracy as a set of methods and procedures enables it adapting with most of political and economic institutions. As shown by experience, democracy system with republic, monarchy, two party and multi-party systems is consistent with capitalism, socialism or welfare government with different types of religious and non-religious beliefs and with various levels of educational progress and economic welfare. ${ }^{6}$ The important thing is the main criteria of democracy eliminating totalitarian political system and turning it to a democrat system. Despite totalitarian system, people perform the rules by satisfaction and they obey rulers not by obligation.

Based on democracy in each society and in each culture they use the cloth of the society and culture. It is natural that democracy as combined with Islam has Islamic features. Despite totalitarian despite totalitarian system democracy system is fully flexible and as inspired by culture, traditions can have the relevant form of the culture. Discussing about democracy is discussing about system efficiency. In religious democracy people rule and with the difference that Islamic society can adapt its own requirements with Sharia as a public origin in Islamic society. Imam Khomeini we want Islamic Republic of Iran, Republics forms the form of government and Islam is the content of the form in divine rules. ${ }^{7}$ Nikolomakiaveli (1469-1527) lived in medieval and Renaissance centuries. At the same time with Luther (1548-1483) changing Catholic tradition he was one of the pioneers complimenting democracy with some changes in its concept in the book of speeches and blamed church as the declining factor. Thomas Moor published the famous work of Utopia (1516) and presented an image of Utopia as a society without any class and democratic and it had great role in formation of democracy thought. In 17th century, after one century of identity crisis of west, great scientists were emerged to respond the questions in their communities. IN this century, social contract followers founded modern democracy. Hobbs, Lock and Russo are famous as social contract followers.

They had influential role in formation and development of modern government. In the book Leviathanas the first political philosophy in English by Hobbs, the first comprehensive explanation about modern government and its functions had crucial role in secularization of government and foundation of individualism as today, it is based on liberalism. John lock (1632-1704) despite pessimistic view of human being, presented a new image of human as they are good behaved, discipline-based and social creatures and they can manage their own society. The theory of Hobbs knowing human being as bad was based on tyranny but lock theory was based on democratic community. Lock states that: The ruler is the other party to people and cannot apply power outside of the contract framework. The main instinct of current democracy is based on John Lock as continuing and establishing government is based on people approval. A book regarding ignorance played important role in separation of church from arguments and in the book as a review of human understanding had important effect on

${ }^{6}$ William Einstein and Edvin Fagman, Contemporary political schools, Translated by Hosseinali Noruzi, p. 240.

${ }^{7}$ Sahifenur, Vol. 4, p.157 knowledge of west. Jean-Jacques Rousseau (1712-1778) wrote social contract book and different interpretations of it were made either in Fascism in Romanticism or the effects of democracy liberal but he believed that pre-requirement of democracy was a society with unified class and it was different from liberal thought as expressed later.

He was the first one who found about majority despotism and in social contract book attempted to solve it and he had concept of legal government and political thought was also considered. I know the Republic government the one being continued under the law control. In such government only public benefit is considered. Emil was effective on education and it was known as the great charter of new era education. Social contract was effective on France Revolution. In Universal declaration of Human rights, it was inspiring. Montesquieu (1689-1775) in the book of spirit of the laws had great role in promoting liberal democracy. The most famous view of Montesquieu in political thought was forces separation theory. Any person with law tries to misuse it and it is forever, in order to avoid misuse of power, power should be used against power.

Despite Bantam, John Stewart Mill (1806-1848) as the first law makers of liberal democracy law and showed it based on human nature and that of society. He believed that they took some solutions by government and tried to save themselves. In the book "political economy principles" condemned unfair distribution of wealth and economic power and requested the support of low classes. For dominance of majority the absolute majority was turned into relative majority that minority was provided in government and it controlled majority. In the early 20th century, reformist liberals raised positive freedom (using talent and its exploitation)-freedom instead of negative freedom (release of external forces-rules, habits, traditions) and it led into the increase of government power in various cultural, social and economic fields for the benefit of deprived class of society. Green, Bsonquet and Vahab Hause were the most important reformist liberals.

Among Islamic theorists, for the first time Farabi (259-339) was the first Muslim political philosopher dividing society into Utopian and Non-Utopian, he considered democracy as non-Utopian city. In the book, Akhlagh Naseri, Khaje Nasiroldin Tusi supported the view of Farabi. Emamie jursits deserted political jurisprudence to constitutionalism era for various reasons. One of the most valuable books of this era is "Tanbie Al-Ome and Tanzihe Al-Mele", by Ghoravi Naili and it is the first book in Shia political jurisprudence and he believed that constitutionalism government was not illegitimate and it was turned into legitimate with the permission of jurists. ${ }^{2}$ Constitutionalism government was legitimate with the permission and by oppression to Imamet and guardianship can be removed by the permission and it can be purified by permission. ${ }^{8} \mathrm{He}$ believed that for legitimacy of constitutionalism government, it is not required that a jurist is on the government and the permission of jurist is adequate but the presence of fair and aware jurists to the law making time with the right of verification and rejection of ratifications can be necessary. ${ }^{3}$ Generally, after revolution, the followers of jurist guardianship are divided into two groups:

\section{Those believing in approving guardianship of jurists}

2. Followers of jurist guardianship selected by people. Shahid Sadr in the book "Al-Islam Yaghudolhayat" was the second type. Nematollah Salehi in the book righteous government

${ }^{8}$ Mohammad Hossein Qoravi Naini, Tanbih Al-Ome and Tanzie Almaleh. Introduction and footnote of Seyed Mahmoud Taleghani, p.75. 
guardianship in 1981 supported the opinion of Shahid Sadr The greatest efforts in this regard are four-Volume book in "oىمالسالا ملودلا مقف و مىقفلا مىالو عف تاس|" by Hosseinali Montezari based on 6 years of teaching. After Imam Khomeini, Shahid Sadr is the second theorist of religion democracy as presenting his theory in Islamic Revolution.

The political system principles include

1. A. political ownership belongs to God,

B. Nobody can dominate another one. The mission of prophet is giving real freedom to people by God as directly and as indirectly in jurists' occultation era can rule.

2. The only law making source is Islam.

3. Human being is divine caliphate and has high divine value. This value is appeared in government via selection of representatives, rejection of legislative power and appointment of chief of executive power among selected jurist people into legislative power.

4. Legitimacy of government by succession of jurists in occultation era is to be as the ruler but his guardianship is only restricted to adaptation of Sharia and social affairs. Thus, jurist is not a guardian in Alfaragh and this field is delegated to people.

5. People have important role in appointment of jurist as leader of Islamic community. The only jurist with actual legitimacy of governing can be selected by people.

Ayatollah Montazeri as the most important theorists of jurist guardianship believes that prophets didn't appoint jurists as their successors and introduced them as qualified candidates to people to select one of them. After appointment, guardianship is actualized and other jurists should follow him. Religion has been used literally in various meanings as obedience, punishment, debt etc. and in metaphor as obedience of Sharia. ${ }^{9}$ The conceptual meaning of religion: Various definitions are expressed in this regard some of them are wide including any tradition as believing in God is not raised in it. Some people have reduced religion to the internalized feeling. ${ }^{10}$ Some people consider belief in monotheism, resurrection and prophet hood

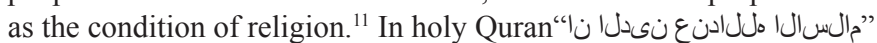

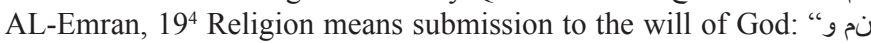

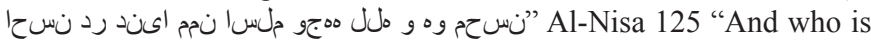
better in religion than one who submits himself to Allah while being a doer of good ". Islam religion: The set of beliefs, ethics as presenting by God through the last Prophet.

Wisdom: And Allah has created you from the wombs of your mothers while you knew nothing, and gave you ears and eyes and hearts so that you may be grateful. (AL-naml, 78). Theoretical wisdom, practical wisdom, instrumental wisdom. ${ }^{12}$ Theoretical wisdom: It refers to the being outside of human being will. The power responding the fundamental questions (who, where, to where, why). In religion rationality, good life is only provided via responding the questions.

\footnotetext{
${ }^{9}$ Al-Ragheb Isfahani, Mofradat Alfaz Al-Quran Karim, Tahghigh Sanavan Adnan

${ }^{10}$ Michel Peterson et al., religious belief, Translated by Ahmad Naraghi and Ebrahim Soltani, 18

"Mohammad Naghi Mesbah Yazdi, Religious knowledge, Mesbah journal. P.20. 1996. P.5.

${ }^{12}$ Hamid Parsania, from divine wisdom to instrumental wisdom, political sciences journal. NO. 19, p.7.
}

After responding them with practical wisdom, values and anti-values were identified and then existing tools were recognized based on ام لك ${ }^{13}$.

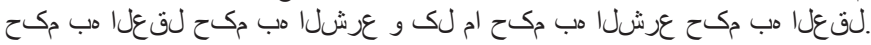
The term wisdom ignoring its derivatives and synonyms is repeated 3688 times in traditions ${ }^{14}$ by which wisdom is the most important divine creature and it is the criterion of punishment and reward. There are various verses regarding using wisdom in Quran as verses 164 of Baghare and AL-Imran 190, Araf 85 as emphasizing on the thought of human being.

Kant was highly inspired by Hume considering ethics as a pure dream of mind. Hume believed that wisdom was the slave of emotions. Islam is a comprehensive tradition including all aspects of life... Islam is an ethical school, social and political purification; it is the ratio of politics and religiosity of soul in body..$^{15}$ Legitimacy in political philosophy means rational justification of dominance. ${ }^{16}$ The position of human being in Islam, Human being is Allah caliphate on earth. Al-Baghare 30. Tafsir AL-Mizan says about this verse as caliphate is called Caliphate Allah. Second, it doesn't only belong to human being and the children of Adam share it. ${ }^{17}$ Respect aspects and keeping this position:

1. Doing religious obligations as doing obligatory and avoiding forbidding things

2. Keeping social norms in Islamic society not being contradicting thought system of society, thought system includes two aspects, one political, another one cultural in two aspects of human being. Everybody should observe both aspects as not contradictory with verses of God. Though system includes two aspects, one political and another culture. In both aspects, human should observe both aspects as not contradictory with verses of God. To guide human being, it is required to increase world view of society and people capacity in Islamic community is increased with religious knowledge as associated with political, cultural issues and development of human being with high thought is increased. The position of human being has ascending process and when human being came to life, he should be careful about his thought process and if human being ignores himself and doesn't reflect, the process is descending as going to the lower parts. Tashria guidance of God is avoiding human being descending from his position.

3. Observing people rights and human community: There are various traditions regarding observing people rights and there are also other verses regarding avoiding tyranny and oppression. This is one of the most fundamental bases of politics and government in Islamic view.

Oppression and not observing people rights has no position in Islamic system. These rights as observed by Islamic system are as follows:

A. Fulfilling the economic needs of people as when poverty enters, faith is eliminated and in economic issues, God has considered development of prosperity in private ownership and also as cooperation.

${ }^{13}$ Mohammadreza Mozafar, Jurisprudence principles, 237, Sheikh Ansari, Rasael Vol. 1, Wisdom issue.

${ }^{14} \mathrm{CD}$ of Noor 2

${ }^{15}$ Morteza Motahari, Leadership and Imamet, 31

${ }^{16}$ Mohammad Javad Larijani, criticism of religiosity and modernism, p. 51.

${ }^{17}$ Mohammad Hossein Tabatabayi, Tafsir ALmizan, Vol. 1, p.116. 
B. Creating cultural ground for growth of cultural factors in society based on verses 17, 18 of Zomar verse, God has given some good news to select the best among the different thought views thus, thought dissemination should be provided and based on some verses as نودلا ىف هاركال نورطسىام و ملقلا و ن ... و ..., there are various traditions regarding the value of thought and its position in a social and cultural ground and people should express their own views based on God religion.

C. Social security: Islamic system is required to provide required security to create good life conditions and investment and thought instruments. It is obvious that ignoring them is ignoring rational foundation of $\mathrm{God}$ religion. 5

\section{Conclusion}

Human being is in ascending process and a happy community full of freedom (freedom of thought, presenting thought, thought process expression as qualified is given by God and no ownership cannot eliminate them), the simultaneous growth with environmental conditions for those believers to eliminate all barriers via thought and wisdom (dynamic effort and perceiving time and place conditions) can be manifested in God speech. People can be away from kingdom and don't accept oppression ownership and in this evolutionary path, a real ownership with the origin of these elite people as their connection point is God can be continuous. The above items show that in Islam, not only there is real democracy (achieving political, social and cultural achievements by Human being), an aspect of extreme aspect is based on God speech and each one is extracted by progress of human being thoughts and his time growth.

\section{Acknowledgements}

None.

\section{Conflict of interest}

Authors declare there is no conflict of interest in publishing the article.

\section{References}

1. Vahidimanesh HA. Comparison of basics of religious democracy and liberal democracy. Education institute publication center of Imam Khomeini, Qom, Iran.

2. Ghazizade K. Jurist guardianship and Islamic government in Imam Khomeini view. Kongere Publications; 1999.

3. Mashallah Ajodani. Iranian constitutionalism,6th ed. Akhtaran publication; 2007.

4. CD of interpretation, translation and reading Holy Quran.

5. www.Andishkadeh.ir 